\title{
Meta-analysis of Holocene fluvial sedimentary archives: a methodological primer
}

Anna F. Jones ${ }^{a, *}$, Mark G. Macklin ${ }^{\text {b,c }}$, and Gerardo Benito ${ }^{\mathrm{d}}$

a School of Geography, Planning and Environmental Policy, University College Dublin, Newman Building, Belfield, Dublin 4, Ireland, anna.jones@ucd.ie

${ }^{\mathrm{b}}$ Department of Geography and Earth Sciences, Aberystwyth University, Llandinam Building, Penglais Campus, Aberystwyth, SY23 3DB, UK, mvm@aber.ac.uk

c Innovative River Solutions, Institute of Agriculture and Environment, Massey University, Private Bag 11 222, Palmerston North, 4442, New Zealand, m.g.macklin@massey.ac.nz ${ }^{\mathrm{d}}$ Museo Nacional de Ciencias Naturales-CSIC, Serrano 115bis, 28006 Madrid, Spain, benito@mncn.csic.es

* Corresponding author

\begin{abstract}
This paper describes developments in the analysis and interpretation of Holocene fluvial chronologies over the past 25 years. Particular consideration is given to meta-analysis approaches pioneered by Macklin and Lewin (2003), using radiocarbon-dated fluvial deposits in Britain, which have transformed fluvial geochronologies and correlations with climate and land-use records worldwide. During the last decade methodological developments have addressed issues such as correction for the shape of the radiocarbon calibration curve in the probability analysis of dated fluvial units and for variable alluvial unit preservation. The number of regional database analyses of fluvial sedimentary archives has also expanded significantly during the past decade, with studies now available for Africa, the Mediterranean region, India, Ireland, New Zealand, Poland, the Rhine catchment and the UK. Methods for incorporating optically stimulated luminescence ages in the probability analysis have also been developed and are illustrated using the database of Eastern Mediterranean dated fluvial deposits. There is considerable potential for meta-analysis research to inform long-term flood risk assessment, to evaluate short-term climate and land-use change impacts on flooding and river behaviour, and to test landscape evolution models.
\end{abstract}

Keywords: River floods; ${ }^{14} \mathrm{C}$ dating; Fluvial sediments; Holocene environmental change 


\section{Introduction}

Mitigation of the impacts of hydrological extreme events presents major challenges to communities globally, not least because temporal variations in floods and their relationship to climate change are not yet well understood in many regions. The principal source of multicentennial and millennial-length records required to investigate changes in the frequency of major floods related to climatic variability is dated fluvial sediment sequences. However, the record of river dynamics and floods preserved within the fluvial sedimentary archive at a single site or study reach is generally fragmentary and incomplete (Lewin and Macklin, 2003). Over the past twenty-five years database and meta-analysis approaches have been developed for using ${ }^{14} \mathrm{C}$-dated sedimentary archives to reconstruct centennial-scale changes in Holocene river activity and flooding over a wide range of spatial scales (Macklin and Lewin, 1993; Macklin and Lewin, 2003; Macklin et al., 2005; Johnstone et al., 2006; Hoffmann et al., 2008; Harden et al., 2010; Macklin et al., 2010a; Macklin et al., 2012b). Following Macklin et al. (2012a), meta-analysis is here defined as "the use of a systematic review procedure and common set of statistical techniques to combine the results of several studies”. The method involves compilation of a database of dated fluvial deposits, classified according to location and sedimentary context, and analysis using probability-based techniques (Johnstone et al., 2006). This approach has so far been applied to radiocarbondated alluvial units in Europe (Macklin et al., 2006; Starkel et al., 2006; Thorndycraft and Benito, 2006a,b; Hoffmann et al., 2008; Benito et al., 2008; Piccarreta et al., 2011, Turner et al., 2010), the American south-west (Harden et al., 2010), North Africa (Zielhofer and Faust, 2008), the Indian subcontinent (Kale, 2007) and New Zealand (Macklin et al., 2012a, Richardson et al., 2013).

Since Johnstone et al. (2006) published a description of the database of British radiocarbondated Holocene fluvial deposits, which has formed a template for the majority of subsequent meta-analysis studies, there have been significant developments in the probability-based analysis of the data as well as additions to the information stored within the database, both to facilitate additional analyses and to incorporate dates from multiple radiometric methods (e.g. optically stimulated luminescence). However, the production of flood chronologies based on radiocarbon dates has also been subject to some criticism, primarily because of the wellknown fluctuations in atmospheric ${ }^{14} \mathrm{C}$ and its influence on the radiocarbon calibration curve (Chiverrell et al., 2011). The objectives of this paper are: (1) to review the development of the databases of Holocene ${ }^{14} \mathrm{C}$-dated fluvial sedimentary units and the methods used in their 
analysis since their conception in the late 1980s and following the publication of the first probability-based analysis of ${ }^{14} \mathrm{C}$-dated Holocene fluvial units in Britain (Macklin et al., 2005), and the current data compilation and analysis protocols used with the British database; (2) to consider some of the differing viewpoints as to the value of this methodological approach to understanding the timing and controls on Holocene fluvial development; and (3) to evaluate emerging and future applications of meta-analysis of large databases of ${ }^{14} \mathrm{C}$-dated fluvial deposits to better understand the impact of environmental change on river systems, using examples from Britain, New Zealand and the Eastern Mediterranean.

\section{Methodologies for the meta-analysis of radiocarbon dated Holocene fluvial sedimentary archives}

\subsection{Developments in database compilation and analysis}

The development of the first database of Holocene radiocarbon-dated fluvial units, the British database, occurred in three main phases (Johnstone et al., 2006). First, regional and national episodes of Holocene alluviation were identified based on the frequency of dated fluvial units in 400-year age intervals (Macklin and Lewin, 1993). This first analysis included 123 alluvial units dated using uncalibrated ${ }^{14} \mathrm{C}$ ages (60), archaeological material (37), pollen biostratigraphy (26) and soil stratigraphy (3). In Macklin’s (1999) analysis, updated to include studies undertaken between 1989 and 1998, only ${ }^{14} \mathrm{C}$-dated fluvial units were used. This study found a correspondence between wetter and/or cooler periods at Bolton Fell Moss in northwest England, identified by cyclic changes in bog wetness (Barber et al., 1994), and frequency maxima of dated fluvial units. In addition, three periods at c. 4050-3950, 17501650 and 950-850 cal. BP were picked out as being characterised by more frequent floods. Interestingly in recent meta-analysis based study of river entrenchment and terrace formation using the enlarged UK database (Macklin et al., 2013), these same periods have also been recognised as times of accelerated incision associated with extreme flood events.

The second phase of meta-analysis methodology development was marked by two innovations. First, Macklin and Lewin's (2003) separation of ${ }^{14} \mathrm{C}$-dated fluvial units on the basis of depositional environment (channel bed deposits, palaeochannel fills, floodplains and flood basins) and second, their recognition of ${ }^{14} \mathrm{C}$ ages (termed 'change' dates) associated with an abrupt modification in sedimentation rate or style indicative of a major flood event or change in flooding regime. Major flood episodes were identified where the $2 \sigma$ calibrated age 
ranges of three or more of the 96 'change' dates overlapped. In 2005 the first probabilitybased record of flooding in Europe spanning the entire Holocene was published (Macklin et al., 2005). This involved the production of a cumulative probability density function (CPDF) of the 263 'change' dates (cf. Macklin and Lewin, 2003). To correct for the influence of the shape of the radiocarbon calibration curve on the results, a CPDF of equally spaced simulated dates was subtracted from the CPDF of the 'change' dates to produce the probability difference curve (Fig. 1). The significance of this publication was twofold: first, by grouping ${ }^{14} \mathrm{C}$-dated sites on the basis of coherent precipitation variability areas in Great Britain (eight in total) (Gregory et al., 1991), regional flood histories were reconstructed; and second, it enabled Holocene flood records in Great Britain to be correlated with high resolution proxyclimate records, with the majority of flood episodes corresponding with periods of cooler and wetter climate. Importantly the regional flood records showed significant variations in flooding before large-scale prehistoric and early historical forest clearance, indicating an underlying climatic control.

Since Macklin et al.’s 2005 paper, further advances have been made in: (1) the classification of dated fluvial units; (2) probability-based analysis and (3) the identification of flooding episodes. The classification of 'change' dates, those associated with a change in sedimentation rate or style indicative of flooding (cf. Macklin and Lewin, 2003), has been refined to include only those dates that provide a maximum age (terminus post quem) for the sedimentological change. These are termed 'change after' dates and are considered to be the most reliable indicators of the timing of changes in flooding regime (Macklin et al., 2010a). A further classification, introduced by Zielhofer and Faust (2008), differentiates between evidence for river activity, in the form of a minerogenic sedimentary unit, and for river stability, indicated by the presence of peat or a palaeosol. This classification complements the 'change after' classification as it is applicable to dates that are not associated with a sedimentary boundary or stratigraphic break. 

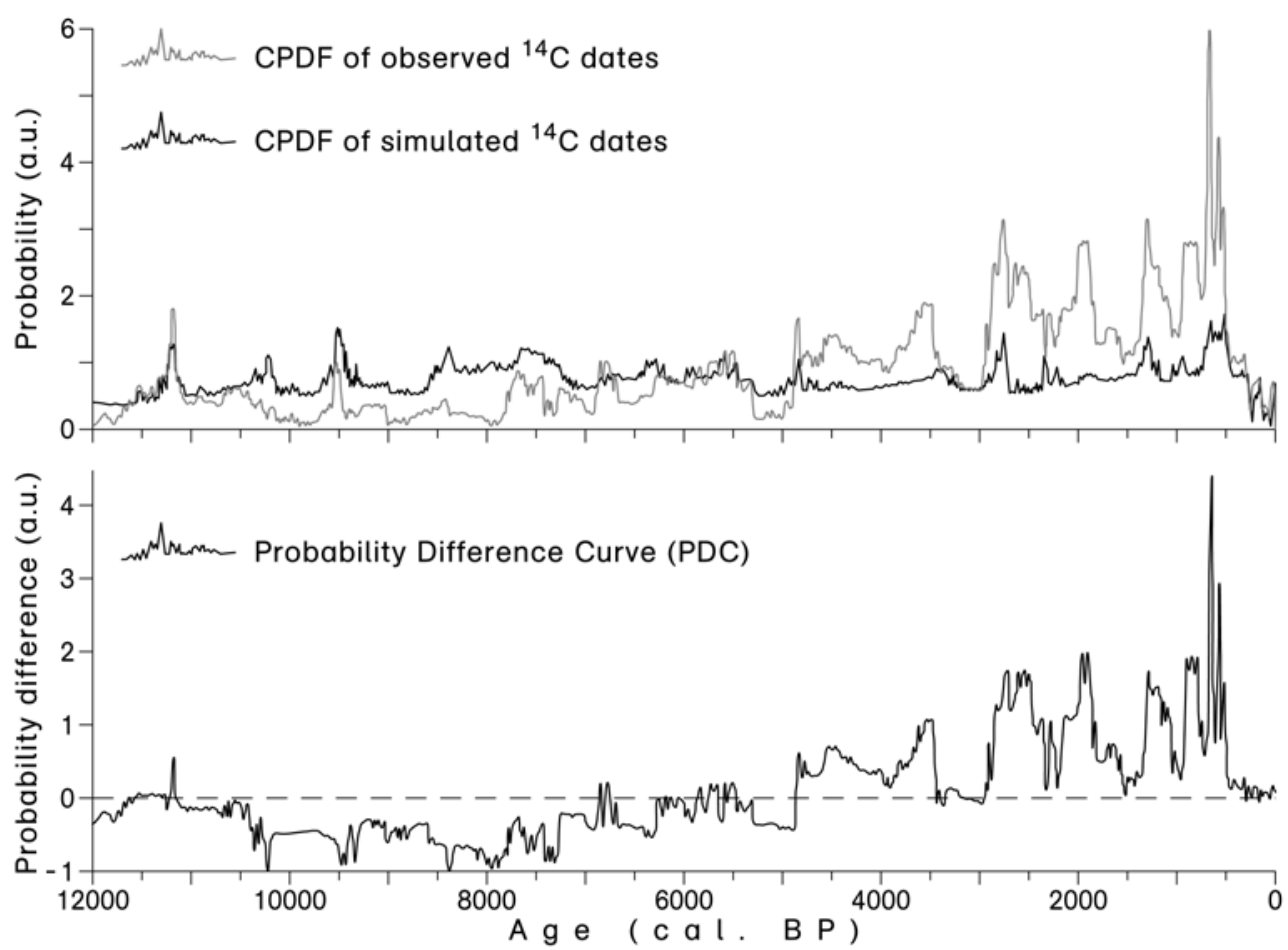

Figure 1: Derivation of the probability difference curve (PDC) for 'change' dates in the British Holocene fluvial record (Macklin et al., 2005). The upper plot shows CPDFs of 263 'change' dates and the corresponding dataset of equally spaced simulated ages, which is subtracted from the observed CPDF. The lower plot shows the resulting PDC. The increase in the number of 'change' dates towards the present shows the effect of variable alluvial unit preservation on the record.

An improved method for removing the influence of the shape of the calibration curve from the probability distribution that also corrects for the effect of variable alluvial unit preservation was introduced by Hoffmann et al. (2008). The probability distribution for 'change after' dates (or any other class of dated samples) is divided by the probability distribution for all dates within the database to produce a relative probability curve (Fig. 2a). The advantages of this method are the simplicity of the calculation, the inclusion of all available dated samples in the analysis and the resulting comparability of relative probabilities throughout the Holocene. Tests of this method by Macklin et al. (2010a), however, indicated the presence of a residual effect of calibration curve shape on the relative probability curve, responsible for low-magnitude oscillations in relative probability and for influencing the exact timing of the major changes in relative probability. 

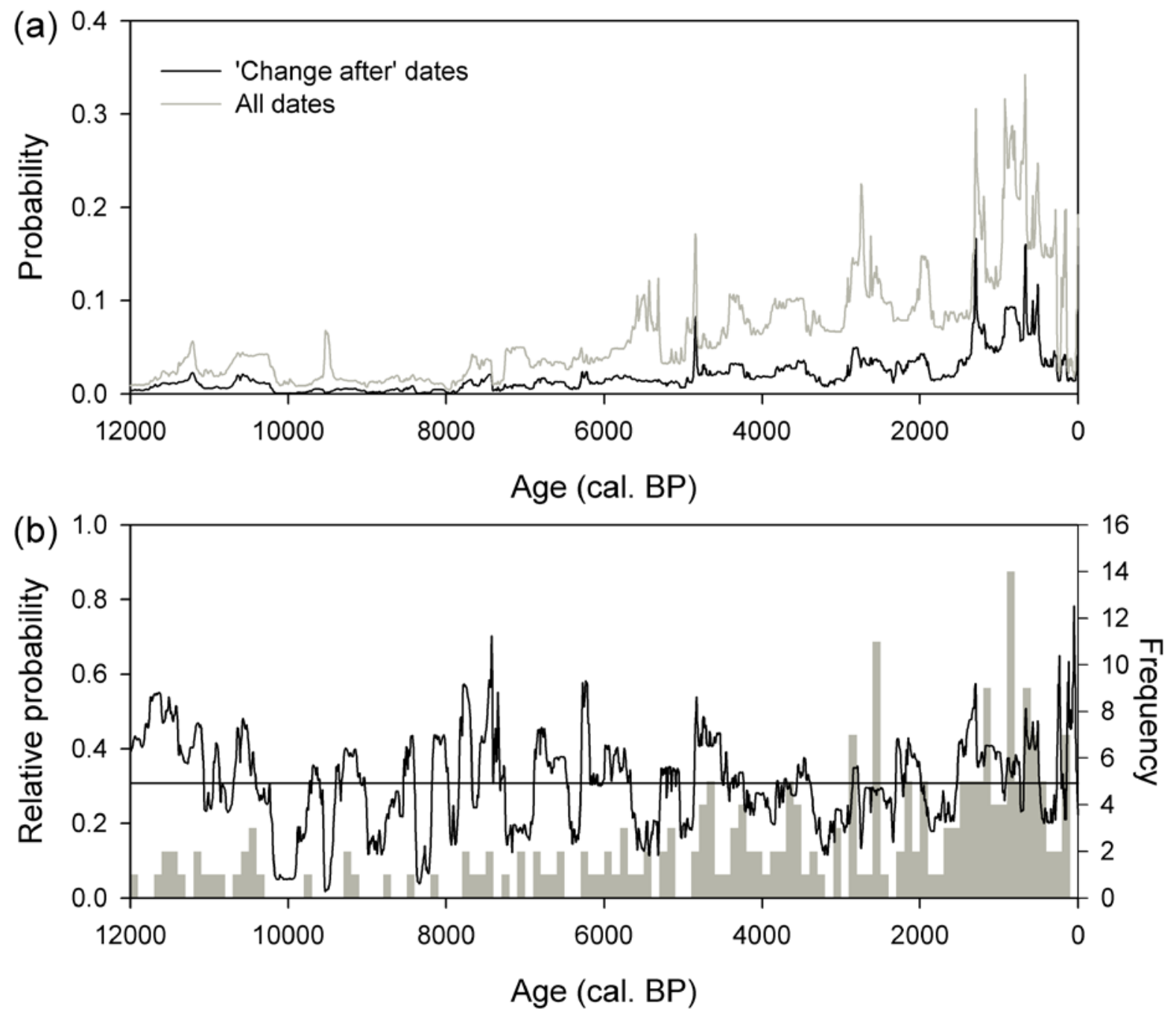

Figure 2: Derivation of the relative probability curve for 'change after' dates in the British Holocene fluvial record (Macklin et al., 2010a). The upper plot (a) shows the probability density functions for the 236 'change after' dates and for all 776 dates. The former was divided by the latter to produce the relative probability curve in the lower plot (b).

As a result of the switch from probability difference curve to relative probability curve (compare Fig. 1b and Fig. 2b), reporting of the timing of flooding episodes has changed from single ages for episode maxima to identifying periods where relative probability is greater than the mean (Harden et al., 2010). Furthermore, as the relative probability curve has been adjusted to account for variable alluvial unit preservation (Hoffmann et al., 2008), it is compared with the frequency of dated samples, represented by the mid-point of the calibrated age, to establish whether the increased relative probability results from sufficient numbers of 'change after' dates to be regarded as an episode of increased flooding (Fig. 2b). The 
beginning and end of each flooding episode are defined to the nearest century because of the residual influence of the calibration curve on the timing of major changes in relative probability.

\subsection{Current database compilation and analysis protocols}

In the current version of the database (Macklin et al., 2012a) each recorded alluvial deposit is represented by a single radiocarbon age. Where duplicate ages are available for a deposit, such as multiple dates on different soil organic fractions or on a single macrofossil, only one age is included in the database. This is, in the case of a macrofossil, the age with the smallest error term or the most appropriate soil fraction for ${ }^{14} \mathrm{C}$ dating. The same approach is adopted where more than one date within a single exposure is associated with a stratigraphic/sedimentological discontinuity; the date with the smaller error term once again is used. Dated alluvial deposits are excluded from the database where either the radiocarbon age or the error term is not reported (an occasional problem particularly in older publications) and/or there is a significant age reversal within a core or exposed section. This may result in exclusion of a single age, where it is clearly incorrect in relation to the other available ages in a sequence, or all ages from the core or section if it is unclear which, if any, dates are reliable.

Classification of dated fluvial deposits is based on information recorded about the sample's location (in the grid co-ordinates or latitude/longitude and elevation fields) and its sedimentary context (Table 1). In the case of the UK, fluvial units are allocated to one of five drainage area classes, assigned to a region of coherent precipitation variability and classified as either upland glaciated or lowland unglaciated catchments. In countries or regions less affected by Pleistocene glaciation, additional or alternative locational classifications have been employed (Macklin et al., 2012a), for example in the case of New Zealand, relating to tectonic or volcanic influences.

The description of each ${ }^{14} \mathrm{C}$ date's sedimentary context is used to classify fluvial units according to depositional environment and, together with locational information, alluvial ensemble (Johnstone et al., 2006). This information is also used to identify 'change after' dates, which provide a maximum age for a flood or for a sustained increase in major flooding. These are most commonly ${ }^{14} \mathrm{C}$ ages recovered from close to the top of either a peat or palaeosol overlain by fluvial sediment or where fine-grained sediments are overlain by coarser fluvial sand or gravel. Proximity of a dated sample to a sedimentological change or 
stratigraphic change is also required for classification as a 'change after' date. For the UK, in peat and fine-grained sediment this is $<10 \mathrm{~cm}$ and for sands and gravels $<30 \mathrm{~cm}$. River activity and stability are identified on the basis of the composition of the unit from which the radiocarbon sample was collected; minerogenic sedimentation indicates river activity while peat and buried soils are indicators of stability.

Table 1: Classification system used within the UK database

\begin{tabular}{|c|c|c|}
\hline $\begin{array}{l}\text { Database fields on which } \\
\text { classification is based: }\end{array}$ & Classification & Categories \\
\hline- & ${ }^{14} \mathrm{C}$ method & $\begin{array}{l}\text { Conventional } \\
\text { AMS }\end{array}$ \\
\hline \multirow[t]{3}{*}{$\begin{array}{l}\text { Locational information } \\
\text { (National Grid Reference or } \\
\text { Latitude / Longitude and } \\
\text { Elevation fields) }\end{array}$} & Drainage area & $\begin{array}{l}<1 \mathrm{~km}^{2} \\
1 \text { to } \leq 10 \mathrm{~km}^{2} \\
10 \text { to } \leq 100 \mathrm{~km}^{2} \\
100 \text { to } \leq 1000 \mathrm{~km}^{2} \\
>1000 \mathrm{~km}^{2}\end{array}$ \\
\hline & Precipitation region & $\begin{array}{l}\text { North Scotland } \\
\text { East Scotland } \\
\text { South Scotland } \\
\text { Northeast England } \\
\text { Northwest England (and North Wales) } \\
\text { Central England } \\
\text { Southwest England (and South Wales) } \\
\text { Southeast England } \\
\text { Northern Ireland }\end{array}$ \\
\hline & $\begin{array}{l}\text { Upland glaciated / lowland } \\
\text { unglaciated }\end{array}$ & $\begin{array}{l}\text { Upland glaciated } \\
\text { Lowland unglaciated }\end{array}$ \\
\hline \multirow[t]{3}{*}{ Sedimentary context } & Depositional environment & $\begin{array}{l}\text { Channel bed and bar sediments } \\
\text { Palaeochannel fills } \\
\text { Overbank sediments } \\
\text { Floodbasin sediments } \\
\text { Debris flow / colluvial sediments }\end{array}$ \\
\hline & 'Change after’ dates & 'Change after' \\
\hline & Activity / stability & $\begin{array}{l}\text { River activity } \\
\text { River stability }\end{array}$ \\
\hline $\begin{array}{l}\text { Sedimentary context and } \\
\text { locational information }\end{array}$ & Alluvial ensemble & $\begin{array}{l}\text { Alluvial fan } \\
\text { Upland stream / gully } \\
\text { Braided / wandering system } \\
\text { Actively meandering system } \\
\text { Inactive meandering system }\end{array}$ \\
\hline
\end{tabular}

Individual 'change after' dates are calibrated using the most recent radiocarbon calibration curve (currently IntCal13 for the Northern Hemisphere (Reimer et al., 2013)) and summed using OxCal (Bronk Ramsey, 2009). The resulting probability distribution is converted to a relative probability curve by dividing each value by the corresponding value in the probability distribution for all dated samples within the database (for a step-by-step guide to 
producing relative probability plots, see supplementary information to Macklin et al., 2012a). The relative probability curve indicates the probability of deposition of a 'change after' date in at least one location relative to the probability of deposition of any sample within the database in a given year. For an accurate indication of variations in relative probability for a particular type of dated sample, the database must contain sufficient dates that are not in the selected category, otherwise the relative probability will remain close to 1 during the majority of the record. Episodes of increased flooding are identified where relative probability exceeds mean relative probability and a minimum of three dated samples in two centuries are present in the frequency plot of the midpoints of the calibrated ages (Macklin et al., 2010a).

Fluctuations in relative probability during the last three centuries are influenced by the introduction of large quantities of fossil carbon to the atmosphere through the combustion of fossil fuels since the start of the industrial revolution (Suess, 1955). For individual ${ }^{14} \mathrm{C}$ dates in this period, the conversion from radiocarbon years to calendar years produces probability distributions with multiple peaks, separated by deep troughs, distributed throughout these three centuries. For instance, $210 \pm 40$ BP gives $2 \sigma$ age ranges (probabilities in brackets) of 420-410 cal. BP (0.6 \%), 316-254 cal. BP (28.5 \%), 225-136 cal. BP (46.2 \%), 114-73 cal. BP (2.9 \%) and after $33 \mathrm{cal}$. BP (17.1\%). In a single-site investigation it may be possible to reject one or more of these age ranges on the basis of available stratigraphic or other chronological information, whereas in the summed probability plot, and therefore also in the relative probability plot, the whole probability distribution for each date is included. The overall tendency of the relative probability in this period (above or below the mean) can be meaningfully compared with earlier periods in the relative probability distribution but the fluctuations in relative probability within these three centuries are unlikely to provide a sound basis for subdividing the period into multiple episodes above and below the mean. Historical, instrumental and lichenometric-dated (Merrett and Macklin, 1999; Foulds et al., 2013) flood records may provide a more detailed and reliable indication of variations in flood occurrence during the past three centuries.

The number of ${ }^{14} \mathrm{C}$ dates required to produce reliable summed probability distributions is an important consideration in the meta-analysis of databases of dated deposits. This was investigated using artificially generated datasets by Michczyńska and Pazdur (2004), who found that for a time interval of $14 \mathrm{ka}$ and with a mean of the standard deviations of the dates in the dataset of 115 years, a minimum of 200 dates was required (statistical fluctuations $<50$ 
\%) and for statistically reliable results (statistical fluctuations $<20 \%) 785$ dates were needed. This equates to a minimum of 14 dates per thousand years and 56 dates per thousand years for statistically reliable results. Using sets of dates randomly sampled from a database of $2748{ }^{14} \mathrm{C}$ dates covering the period 0-50 ka, with a mean of standard deviations of 170 years, Williams (2012) concluded that at least $500{ }^{14} \mathrm{C}$ dates were required to produce a statistically reliable summed probability distribution and that summed probability plots produced using fewer than 200-500 dates should be regarded as provisional as they are liable to change substantially as the database expands. To date, there has been no assessment of the numbers of dates required to produce a statistically reliable relative probability distribution and whether this number is greater or less than that for a summed probability distribution for the same time period. The effect of an increase in the number of ${ }^{14} \mathrm{C}$ dates on the relative probability of 'change after' dates in the British database is investigated in the following section.

\subsection{UK database development over the last decade}

To illustrate how recent developments in database compilation and the meta-analysis of Holocene fluvial deposits have influenced the reconstruction of long-term flood histories, the UK is used as a case study. This database has expanded from $504{ }^{14} \mathrm{C}$-dated units in 2004 to 844 at present, with an increase in the number of 'change after' dates from 171 to 252 (Table 2). The proportion of dated fluvial deposits from lowland unglaciated catchments rose from $27 \%$ to $34 \%$. The growth in number of dated units has been unevenly distributed between the eight coherent precipitation regions, with substantial increases in Northwest, Southwest and Central England, more modest increases in Northeast and Southeast England and South Scotland, and no additions in North and East Scotland. The increase in the proportion of ${ }^{14} \mathrm{C}$ dates on plant matter, from $2 \%$ in 2004 to $10 \%$ at present, indicates a growing tendency for dating plant macrofossils with relatively short lifespans in order to improve the accuracy and precision of ages. The high proportion of dated samples from palaeochannel sediments, almost $70 \%$ of the 340 dates added since 2004, highlights the recent focus of sample collection within these environments, partly because of commonly better preservation of organic material but also reflecting the research priorities of investigators. 
Table 2: Classification of the dates in the British database

\begin{tabular}{|c|c|c|}
\hline Classification and classes & $\begin{array}{l}\text { Number of samples in class in } \\
\text { the } 2004 \text { analysis } \\
\text { (504 dates in total) }\end{array}$ & $\begin{array}{l}\text { Number of samples in class } \\
\text { currently in the database } \\
\text { (844 dates in total) }\end{array}$ \\
\hline \multicolumn{3}{|l|}{ Drainage basin size } \\
\hline$<1 \mathrm{~km}^{2}$ & 77 (15 \%) & 109 (13\%) \\
\hline 1 to $\leq 10 \mathrm{~km}^{2}$ & $79(16 \%)$ & $98(12 \%)$ \\
\hline 10 to $\leq 100 \mathrm{~km}^{2}$ & $65(13 \%)$ & $87(10 \%)$ \\
\hline 100 to $\leq 1000 \mathrm{~km}^{2}$ & $213(42 \%)$ & 394 (47 \%) \\
\hline$>1000 \mathrm{~km}^{2}$ & $70(14 \%)$ & $156(18 \%)$ \\
\hline \multicolumn{3}{|l|}{ Precipitation region } \\
\hline North Scotland & $84(17 \%)$ & $84(10 \%)$ \\
\hline East Scotland & $40(8 \%)$ & $40(5 \%)$ \\
\hline South Scotland & $43(9 \%)$ & $56(7 \%)$ \\
\hline Northeast England & $128(25 \%)$ & $172(20 \%)$ \\
\hline Northwest England and North Wales & $26(5 \%)$ & $95(11 \%)$ \\
\hline Central England & $72(14 \%)$ & $152(18 \%)$ \\
\hline Southwest England and South Wales & $70(14 \%)$ & $169(20 \%)$ \\
\hline Southeast England & $41(8 \%)$ & $73(9 \%)$ \\
\hline Northern Ireland & $0(0 \%)$ & $3(0.4 \%)$ \\
\hline \multicolumn{3}{|l|}{ Upland glaciated / lowland unglaciated } \\
\hline Upland glaciated & 367 (73 \%) & 559 (66 \%) \\
\hline Lowland unglaciated & $137(27 \%)$ & $285(34 \%)$ \\
\hline \multicolumn{3}{|l|}{ Depositional environment } \\
\hline Channel bed and bar sediments & $61(12 \%)$ & $70(8.3 \%)$ \\
\hline Palaeochannel fills & $146(29 \%)$ & $383(45.3 \%)$ \\
\hline Overbank sediments & 176 (35\%) & $261(30.9 \%)$ \\
\hline Floodbasin sediments & $112(22 \%)$ & $119(14.1 \%)$ \\
\hline Debris flow / colluvial sediments & $9(2 \%)$ & $11(1.3 \%)$ \\
\hline \multicolumn{3}{|l|}{ 'Change' / 'change after' dates } \\
\hline ‘Change’ dates & 263 (52 \%) & \\
\hline 'Change after' dates & & $252(30 \%)$ \\
\hline \multicolumn{3}{|l|}{ Activity / stability } \\
\hline River activity & & 404 (48 \%) \\
\hline River stability & & 376 (45 \%) \\
\hline
\end{tabular}

Fifteen episodes of increased river instability and flooding, as shown by the relative probability of 'change after' dates, have occurred in British river catchments during the Holocene (Fig. 3 and Table 3). Episodes of river instability and flooding are unevenly distributed through the Holocene, with frequent or prolonged episodes before $10000 \mathrm{cal}$. BP, between 8000 and $4000 \mathrm{cal}$. BP and after $1500 \mathrm{cal}$. BP. There is a noticeable gap between 10000 and $8000 \mathrm{cal}$. BP, a period for which relatively small numbers of dates are available in the UK, and insufficient numbers of 'change after' dates are present for peaks during this period to be considered episodes of increased flooding. The proportion of 'change after' dates, counted per thousand years, is at its lowest during this part of the Holocene, both in the UK as a whole and in the upland glaciated catchments of northern and western Britain, which are the source of $66 \%$ of the dated samples. 


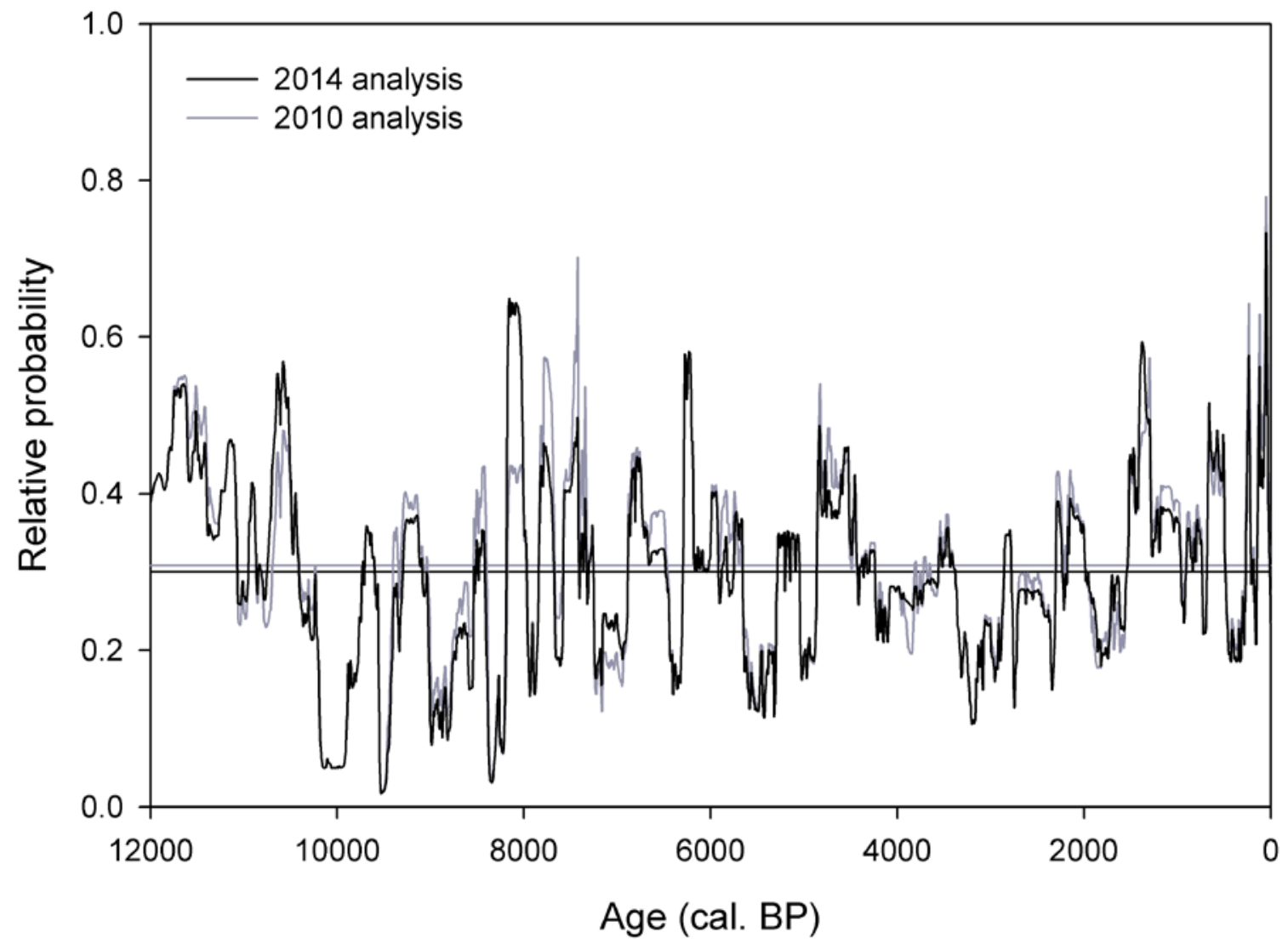

Figure 3: Relative probability of 'change after' dates in the latest analysis (844 dates in total; 252 'change after' dates) compared with the previous published analysis (Macklin et al., 2010a; 776 dates in total, 236 ‘change after’ dates).

Table 3: Episodes of major flooding in Britain

\begin{tabular}{|c|c|c|}
\hline $\begin{array}{l}\text { Episodes of major Holocene riverine } \\
\text { flooding identified from the PDC of } \\
{ }^{14} \mathrm{C} \text { dated fluvial units in British } \\
\text { rivers (Macklin et al., 2005) } \\
\text { (506 dates; } 263 \text { 'change dates') }\end{array}$ & $\begin{array}{l}\text { Episodes of major flooding in the } \\
\text { UK, based on the } 2010 \text { analysis of } \\
{ }^{14} \text { C-dated Holocene fluvial units } \\
\text { Macklin et al., 2010a) } \\
\text { (776 dates; } 236 \text { 'change after' dates) }\end{array}$ & $\begin{array}{l}\text { Episodes of major flooding in the } \\
\text { UK, based on the latest analysis of } \\
{ }^{14} \text { C-dated Holocene fluvial units } \\
\text { (this study) } \\
\text { (844 dates; } 252 \text { 'change after' dates) }\end{array}$ \\
\hline \multirow[t]{5}{*}{11160} & $11800-11100$ & $11800-11100$ \\
\hline & $10700-10400$ & $10700-10400$ \\
\hline & $9400-9100$ & $9300-9100$ \\
\hline & $7800-7700$ & 7800-7700 \\
\hline & $7600-7300$ & $7600-7300$ \\
\hline 6820 & $6900-6500$ & 6900-6500 \\
\hline 5730 & $6300-6200,6000-5700$ & $6300-5700$ \\
\hline \multicolumn{3}{|l|}{5540} \\
\hline & $5300-5100$ & $5300-5100$ \\
\hline 4840,4520 & $4900-4500,4300-4200$ & $4900-4200$ \\
\hline \multirow[t]{2}{*}{3540} & $3600-3400$ & $3600-3400$ \\
\hline & $2900-2800$ & 2900-2800 \\
\hline \multicolumn{3}{|l|}{2730} \\
\hline \multicolumn{3}{|l|}{2550} \\
\hline 2280 & $2300-2000$ & $2300-2000$ \\
\hline \multicolumn{3}{|l|}{1950} \\
\hline \multicolumn{3}{|l|}{1650} \\
\hline 1290 & $1500-1000$ & 1500-1000 \\
\hline \multirow{2}{*}{$860,660,570$} & $900-500$ & $900-500$ \\
\hline & $300-0$ & 300-0 \\
\hline
\end{tabular}


Comparison of the relative probability curve of the 252 'change after' dates in British Holocene fluvial units (Fig. 3) with the probability difference curve of 263 'change’ dates produced in 2004 (Fig. 1) illustrates the effects of the developments in the meta-analysis method during the past decade on the interpretation of the British Holocene alluvial archive. Of the 16 peaks identified in the PDC (Macklin et al., 2005), eleven fall within episodes of flooding identified in the relative probability plot (Table 3), while two further peaks, at 2730 and $1950 \mathrm{cal}$. BP, occurred 50 and 70 years after the end of a flooding episode in the relative probability plot. In addition to the increase in the number of dated fluvial units between 2004 and 2011, the small shifts in the timing of flooding phases, together with the absence of evidence for flooding episodes at c. 5540, c. 2550 and c. 1650 cal. BP can be attributed to two factors. First, the change from probability difference curve to relative probability plot produces a much greater distinction between peaks and troughs, as well as removing the effect of fluvial unit preservation, which is now considered using the frequency of calibrated ages. Second, the refinement of the classification from 'change' to 'change after' dates has standardised the association between the age of a dated fluvial unit and the evidence of flooding. Considering that quite significant methodological changes have been made between the two analyses there is a notable consistency in the results and reconstructed Holocene flood histories.

The addition of each dated fluvial unit will slightly alter the probability distribution for the whole database and, if the date is associated with a subsequent sedimentological change, also that for 'change after' dates. In order to examine the robustness of the method, in terms of identifying flooding using the relative probability plot, the results of the analysis presented here are compared with the previous published analysis for 'change after' dates (Macklin et al., 2010a). The number of dated samples has increased from 776 to 844 , while the number of 'change after' dates has increased from 236 to 252, leaving the proportion of 'change after' dates almost unchanged (0.299 compared with 0.304 previously). A comparison of the flooding episodes identified in the two separate analyses shows that one episode has been reduced in length by a century (9400-9100 became 9300-9100 cal. BP) and, due to the adjustment of the mean, there are two cases in which two episodes have been combined (4900-4500 with 4300-4200 cal. BP and 6300-6200 with 6000-5700 cal. BP). The most striking difference between the two relative probability plots is the increase in the magnitude of the peak at 8200-8000 cal. BP but there are still insufficient dated samples in this interval for it to be identified as an episode of increased flooding, using the criterion of at least three 
dated fluvial units in two consecutive centuries (cf. Macklin et al., 2010a). A quantitative comparison of the two series gives a Pearson correlation coefficient of 0.94 over the whole time period and correlation coefficients of 0.9 or greater for 102 out of the 120 centuries in the series, 67 of those at 0.99 or greater. Only two centuries produced negative correlation coefficients between the two data series, in 3700-3600 cal. BP and 1400-1300 cal. BP, in each case where there have been increases in both 'change after' dates and other dated samples between the two analyses. For all intents and purposes the timing of flooding episodes identified by these two separate analyses is identical, suggesting that, with the numbers of dated units and proportion of 'change after' dates currently in the UK database, the analysis is relatively insensitive to small additions to the number of dated fluvial deposits, except where the frequency of dated units is low.

\subsection{Inclusion of OSL ages: the Eastern Mediterranean database}

With the exception of the first analysis of dated Holocene fluvial units in Britain (Macklin and Lewin, 1993), meta-analysis of Holocene fluvial archives has been applied exclusively to

${ }^{14} \mathrm{C}$-dated river sediments. Deposits dated using ${ }^{14} \mathrm{C}$ constitute the vast majority of dated fluvial units in the UK and in many parts of the world but other radiometric methods, most notably luminescence dating techniques, have been widely employed in the study of Holocene fluvial sediments, particularly OSL dating in the European Mediterranean region (Macklin et al., 2010b). In the light of this, database compilation and analysis procedures have been adapted in order to incorporate luminescence-dated fluvial deposits (see Benito et al., 2014, this volume). Although this is not difficult in practice, two principle differences between luminescence and radiocarbon dating must be considered in data preparation and interpretation of the results. First, OSL dating of fluvial sediments directly dates minerogenic material within a sedimentary unit, unlike ${ }^{14} \mathrm{C}$ which is performed on incorporated organic material that gives either a terminus pre quem or terminus post quem age for the deposition of a fluvial unit. This difference is important for the interpretation of the resulting probability distributions. Second, OSL ages have normally distributed probabilities and do not require calibration to calendar years, affecting data preparation. However, incomplete bleaching of an OSL sample during sediment transport may result in an age older than the true age of a depositional event, potentially transposing or creating additional apparent flooding episodes within the probability distribution. Incomplete bleaching may be identified in the original publication of an OSL age, allowing the date to be excluded from the analysis, but this is not 
always the case, particularly in older publications. In individual studies for which a large number of OSL ages have been obtained it may be possible to identify anomalously old ages by comparison with others from the same sedimentary unit, or from overlying or underlying units (e.g. Busschers et al., 2007). Current development of age models for incompletely bleached sediments (e.g. Sim et al., 2014; Medialdea et al., 2014) may enable inclusion of affected samples in probability analyses of dated samples in future.

The recently compiled Eastern Mediterranean database of dated Holocene fluvial units is used here to illustrate how the meta-analysis method can be successfully modified to incorporate luminescence-dated fluvial deposits. Records of OSL-dated fluvial units are separated from those of ${ }^{14} \mathrm{C}$-dated fluvial deposits because the information required is different for each type. For example, details of the OSL-dating protocol, the mineral and grain size fractions analysed are recorded instead of radiocarbon method and type of organic matter dated. Likewise, information relating to the calibration of ${ }^{14} \mathrm{C}$ ages has been substituted with fields for converting published OSL ages to either calendar years or years before AD 1950. This is particularly important where OSL ages have small errors (e.g. $< \pm 20$ years), which occurs most frequently for samples dated to the last millennium. In cases where the year in which an OSL sample was dated is not given, the year of publication has been used to convert ages to calendar years and years before AD 1950.

The Eastern Mediterranean ${ }^{14} \mathrm{C}$ ages were calibrated, using the IntCal13 calibration curve (Reimer et al., 2013), and ${ }^{14} \mathrm{C}$ and OSL ages were summed using OxCal v. 4.2 (Bronk Ramsey, 2009). The results (Fig. 4A) give probabilities extending more than 1000 years into the future. This analysis contains OSL and ${ }^{14} \mathrm{C}$ ages which would normally be excluded because of the magnitude of the error term. However, they are retained here for the purpose of demonstrating an effect which still occurs, albeit to a much smaller extent, when the dates with large errors are excluded. In order to eliminate future probabilities, each OSL age was combined with a uniform probability density function to constrain the modern limit of the probability of each sample's age to be the year of sample collection, if available, or the year of publication. This uniform PDF was extended sufficiently far backwards in time to exert no influence on the earliest possible age of the sample. The adjusted summed probability distribution (Fig. 4B) no longer extends beyond the present and shows slightly increased probabilities, during some time periods, relative to the original summed probability distribution. 


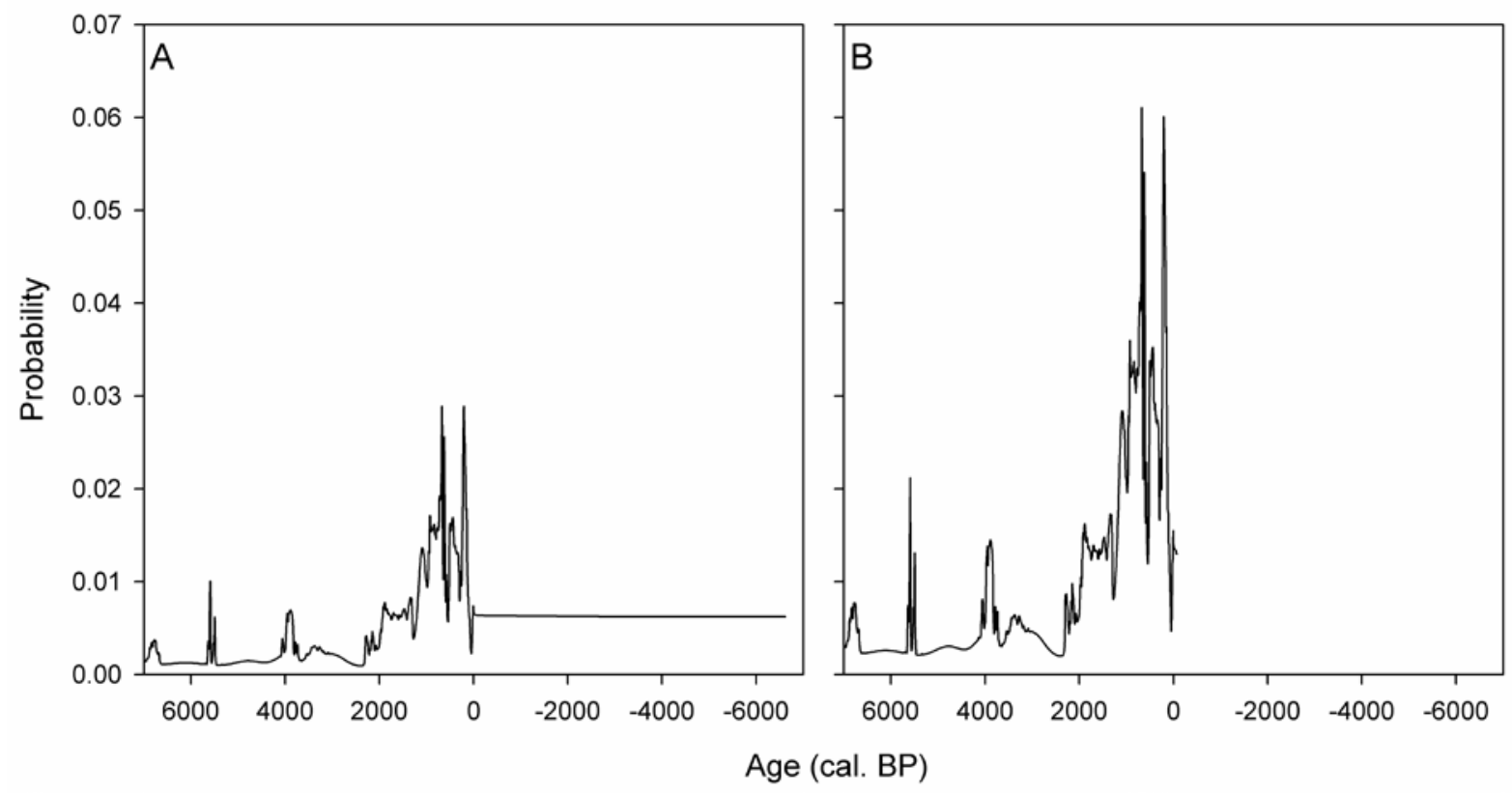

Figure 4: Probability plots of all ${ }^{14} \mathrm{C}$ and OSL ages in the Eastern Mediterranean database, showing the effect of the correction to eliminate future probabilities. A: Uncorrected probability distribution; B: corrected probability distribution.

The summed probability and relative probability distributions are a combination of the irregular probability density functions associated with the calibrated ${ }^{14} \mathrm{C}$ dates and the smooth curves resulting from the normally distributed probabilities of the OSL ages (Fig. 5). However, some caution is required in interpreting these plots as OSL ages are ages of sediment deposition while the ${ }^{14} \mathrm{C}$ ages provide a terminus post quem for a depositional event. For this reason, comparison of separate analyses of OSL and ${ }^{14} \mathrm{C}$ ages with the combined analysis may prove useful in understanding the patterns of variability in flood occurrence and alluviation. Nevertheless, the facility to include available OSL ages within the meta-analysis framework provides an opportunity to substantially expand the numbers of dated alluvial units used in the analysis of Holocene river development and flooding, and to extend application of the methodology to additional regions in which OSL-dated river sediments are a significant component of the Holocene fluvial archive. 


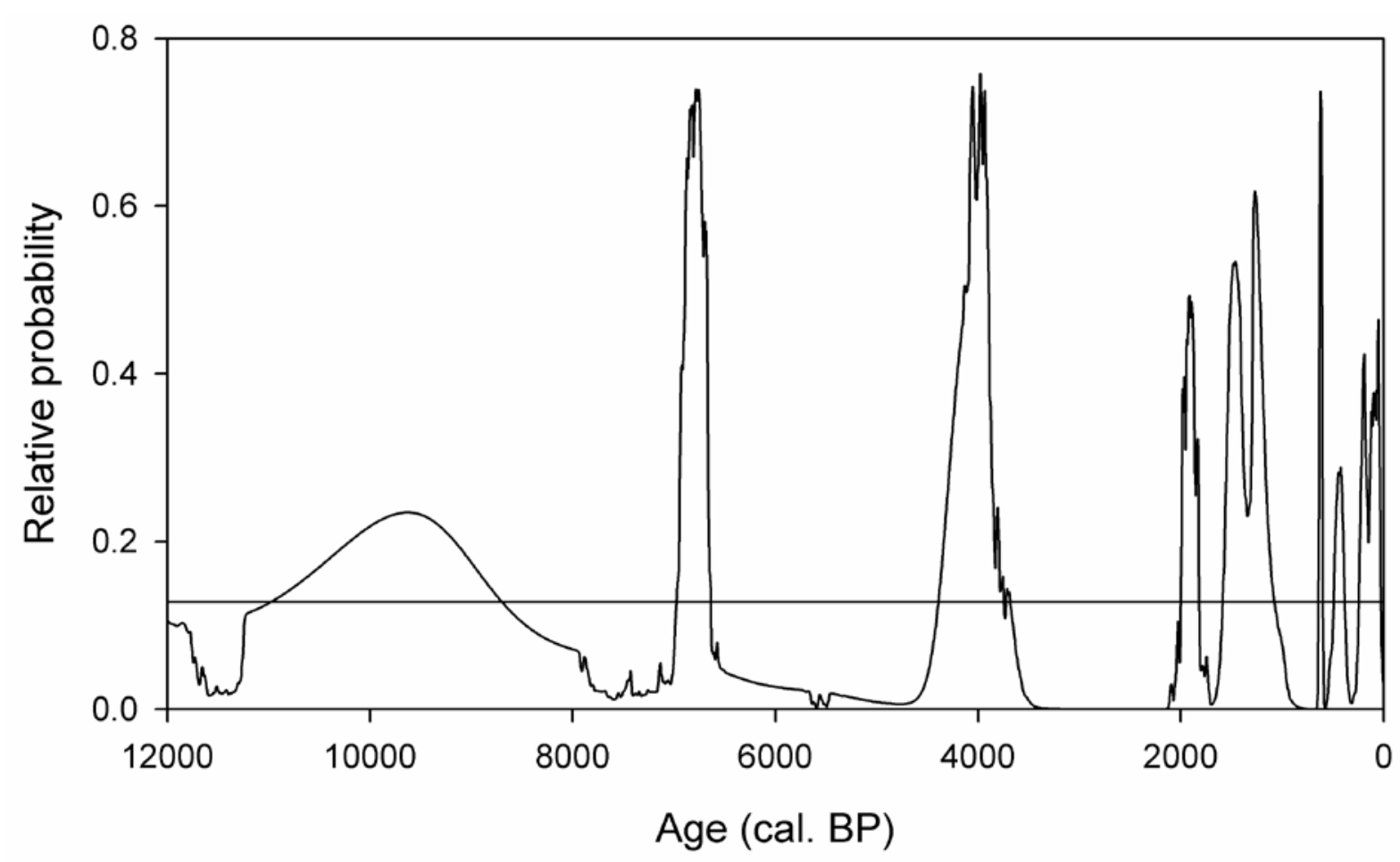

Figure 5: Relative probability plot of 'change after' dates for the Eastern Mediterranean, showing the effect on the shape of the curve of combining OSL and ${ }^{14} \mathrm{C}$ ages in a single analysis.

\section{A guide to the use of meta-analysis and the interpretation of relative probability}

\section{distributions of ${ }^{14} \mathrm{C}$-dated units in fluvial environments}

The main objective of what has come to be known as 'meta-analysis' in Holocene river research has been to discern emergent and spatial patterns in the fluvial record, using large ${ }^{14} \mathrm{C}$ databases from multiple catchments (Macklin et al., 2011). This produces an aggregated record that enables dated fluvial sequences to be compared and correlated with a wide range of proxy climate records and human activity indicators in a manner not otherwise possible. When first employed by Macklin and Lewin (2003) more than 10 years ago, it sought, using standard data compilation and statistical analysis, to better understand the rapidly growing number of site- and reach-based Holocene river studies in Britain. Macklin and Lewin, by adopting a data-led methodology, wanted to go beyond the necessarily arbitrary literaturebased approaches, which had hitherto been used for regional and larger-scale correlations. Meta-analysis as originally conceived by Macklin and Lewin, and later developed in conjunction with their co-workers Johnstone and Jones, is not intended for dating of individual flood events (as asserted by Chiverrell et al., 2011), for which the temporal 
resolution of the radiocarbon method is inadequate, but for the identification of 'episodes' of increased flood occurrence. 'Episodes' in this context are defined as clusters of major floods identifiable within the ${ }^{14} \mathrm{C}$-dated fluvial sedimentary record at the centennial and multicentennial scale. Such clustering of major floods is evident in instrumental, historical and palaeoflood records at a range of temporal scales (e.g. Ely et al., 1993; Macklin and Rumsby, 2007). Due to the nature of the data, it would be possible for an 'episode' of increased flood occurrence identified in the relative probability distribution to be produced by a single major flood event which generated 'change after' dates at multiple sites either within a single catchment or in a number of different catchments. An inspection of the UK database indicates that the incidence of multiple 'change after' dates in individual catchments which, judging from their probability distributions, could be attributed to a single flood event is relatively small.

The meta-analysis approach has been criticised for a perceived loss of information in comparison with single-site analyses (Chiverrell et al., 2011). However, the individual dated fluvial deposits have all been subjected to single-site analyses by the sample collectors prior to their inclusion in the database, so that meta-analysis in fact represents a net gain in information. In the multi-catchment analysis, careful classification of dated sedimentary units (see section 2 above) is the key to obtaining meaningful results. Although Bayesian analysis of radiocarbon-dated samples from individual sites has been suggested as an improvement on the multi-catchment analysis, such analyses have a widely different purpose from the metaanalysis described here and therefore cannot be considered as an alternative for regional-scale assessment of variation in flood frequency. Bayesian analysis of ${ }^{14} \mathrm{C}$-dated fluvial units from individual sites and probability-based meta-analysis of multiple sites or catchments are not mutually exclusive but should be viewed as potentially complementary approaches, provided that in both cases data standards are met. For example, while Bayesian modelled ages at single sites slightly improve the dating precision of flood episodes, this analysis is highly dependent on the number of dates at a single site and, as recognised by Thorndycraft et al. (2012), should one of the ages in a section be erroneous then so too is the flood frequency interpreted from the Bayesian age models. 


\section{Emerging uses of meta-analysis for the interpretation of Holocene river dynamics}

The compilation of databases of radiocarbon-dated fluvial units over the last decade or so, in conjunction with developments in meta-analysis, has provided additional opportunities to investigate the controls on Holocene river development (see Macklin et al., 2012b for a review). This has included disentangling the ways in which multiple allogenic and autogenic factors influence the fluvial sedimentary record. For instance, division of 'change after', river activity or stability dates on the basis of sedimentary environment, or between glaciated and unglaciated catchments, has provided further insights into regional Holocene flood occurrence, and the influence of channel and floodplain processes on fluvial unit preservation in British catchments (Lewin et al., 2005; Johnstone et al., 2006; Macklin et al., 2010a) as well as long-term variations in sedimentation rates (Macklin et al., 2010a; Richardson et al., 2013).

The database of UK Holocene fluvial units has recently been used to investigate the timing of river incision episodes during the Holocene (Macklin et al, 2013). Although channel bed incision leaves no record in alluvial deposits, its timing can be constrained by dating the periods of sedimentation which preceded and succeeded the incisional phase, which provide a maximum and minimum age, respectively, for an entrenchment episode. Eighty-three dated fluvial units were found to provide constraining ages for the onset of river incision, with five episodes (4200-3700, 3100-2900, 2100-1900, 1800-1500 cal. BP and most notably the last 1000 years) of channel entrenchment identified in northern and western British rivers during the last 4500 years (Fig. 6A). The differences in elevation between successive dated terrace surfaces in five catchments in northern Britain indicate long-term incision rates of between 0.43 and $0.81 \mathrm{~m} / \mathrm{ka}$. 

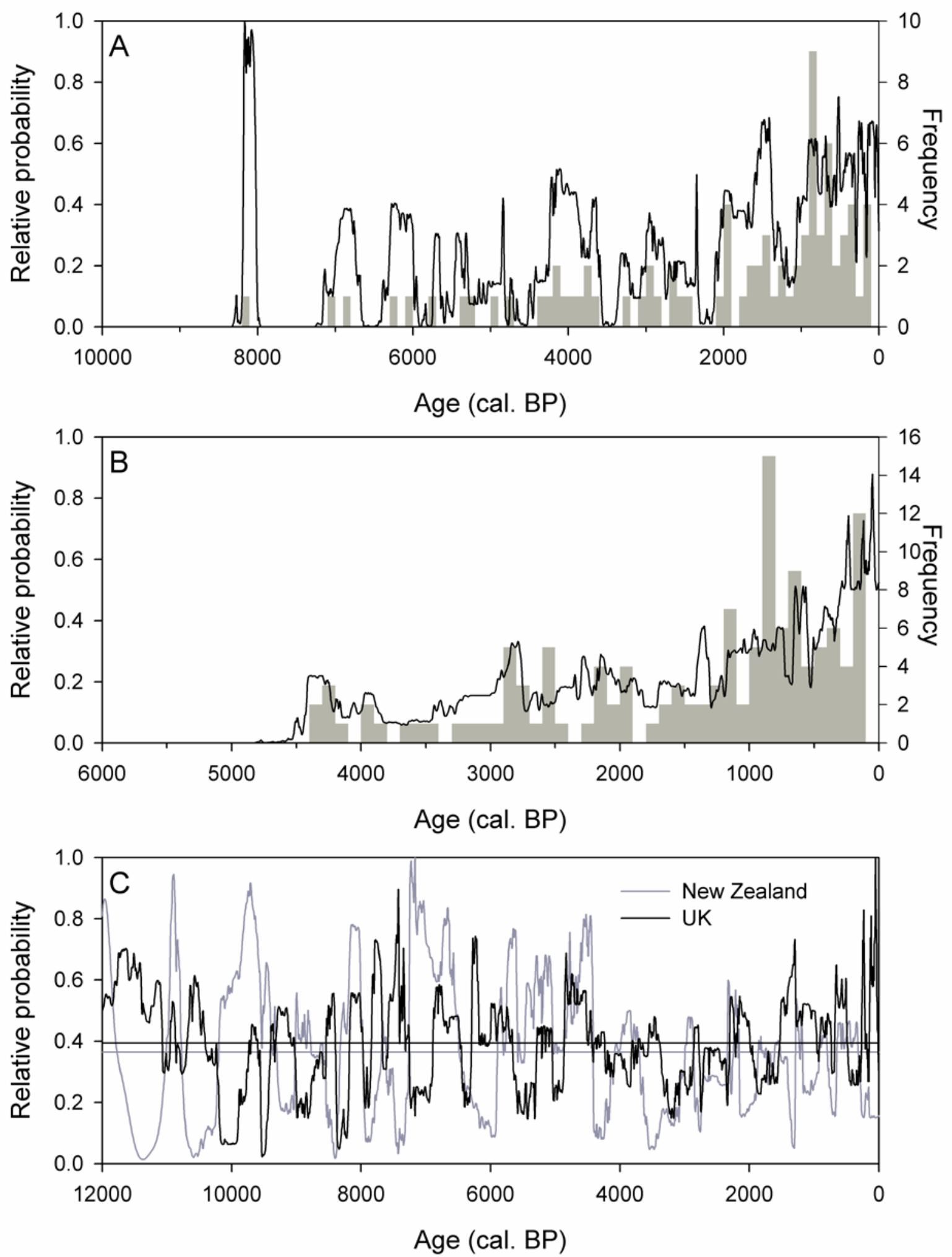

Figure 6: Examples of the potential of meta-analysis for elucidating various aspects of Holocene river dynamics and hydroclimate (Macklin et al., 2013). A: Relative probability, and the frequency of calibrated ages, of the onset of Holocene incision episodes in the UK; B: Relative probability, and the frequency of calibrated ages, of the deposition of anthropogenic alluvium in the UK (Macklin et al., in press); C: Comparison of the timing of episodes of Holocene flooding in the UK and New Zealand using scaled relative probability series (Macklin et al., 2012a). 
The occurrence and distribution of anthropogenic alluvium in UK catchments has also been investigated using meta-analysis of ${ }^{14} \mathrm{C}$-dated British Holocene fluvial deposits (Macklin et al., 2014). All publications in the database were reviewed to determine whether or not each dated fluvial unit could be linked to human impact and, if so, to assign it to one of five types of alluvia: deforestation, cultivation, engineered, mining and undefined. Six criteria were used to identify alluvia of anthropogenic origin: sediment provenance, colour, texture or stratification, the presence of cultural artefacts or pollutants, and biological evidence of anthropogenic activity (e.g. pollen associated with farming) at the site or in the catchment at the time of deposition. This information was entered into the database and the dated units were also classified according to sediment grain size. A total of 130 dated samples, from the Early Bronze Age (c. 4400 cal. BP) onwards, provided evidence of anthropogenic alluviation (Fig. 6B), with evidence of accelerated fine-grained sedimentation occurring particularly during the medieval period. A regional analysis indicated that anthropogenic alluvium formed earlier in the central and southern parts of the UK than elsewhere.

The standardized methods employed to review and compile fluvial sedimentary unit data into databases facilitate analyses at an international scale. The first international assessment was Macklin et al.'s (2006) comparison of three European databases of radiocarbon-dated fluvial deposits from Great Britain, Spain and Poland. Containing more than 1100 dated samples, this study evaluated the influence of both fluvial environment and research strategies on the dated Holocene fluvial record. Meta-analysis using the probability difference curve method identified fifteen episodes of major flooding occurring simultaneously in at least two of these three countries. Eleven of these flooding episodes were also found to coincide with higher mid-European lake levels (Magny, 2004). A second, more recent, international comparison, investigated inter-hemispheric Holocene climate change using analysis of UK and New Zealand fluvial sedimentary sequences (Macklin et al., 2012a). During much of the Holocene episodes of major flooding in the UK and New Zealand were asynchronous (Fig. 6C), suggesting that Holocene climate changes in the temperate maritime zones of the Northern and Southern Hemispheres were out-of-phase.

Regional-scale records of Holocene flooding and river activity can be compared with a range of climate proxies and land-use change indicators, demonstrating the utility of the metaanalysis approach for predicting likely river response to future environmental change (Gregory et al., 2006). Episodes of increased flood occurrence at the centennial and multi- 
centennial scale can be related to large-scale shifts in atmospheric circulation, to identify controls on the frequency of extreme precipitation events. The UK Holocene fluvial record has been shown to track short-term climatic changes (Macklin et al., 2010) driven by pulses of cold water recorded in the North Atlantic drift ice index (Bond et al., 2001). In the Indian subcontinent, clusters of radiocarbon dates indicate that centennial to millennial scale variations in fluvial activity were intimately linked to long-term fluctuations in monsoon strength during the Late Quaternary (Kale, 2007). In the Atlantic rivers of the Iberian Peninsula, Late Holocene flood clusters were linked to the negative mode of the North Atlantic Oscillation index, reconstructed using documentary and proxy records (Benito et al., 2008).

\section{Conclusions}

During the past decade there have been significant developments in meta-analysis methods for the interrogation of dated Holocene fluvial sedimentary archives. This has been accompanied by substantial expansion in the numbers of dated Holocene fluvial units worldwide, particularly in Europe. Methodological developments have addressed issues such as the influence of variable fluvial unit preservation, and have refined the classification of dated alluvial deposits. Some of these problems are inherent in sampling of all types of Holocene deposits, and are partially resolved by careful selection of the most suitable fluvial environments (e.g. floodplain, palaeochannel fill, and floodbasin) for preserving flood events and including only those ages reflecting a change in sedimentation style or rate. Analysis of the expanded database of UK Holocene fluvial deposits using the updated methodology has provided a more complete assessment of temporal variations in Holocene flooding, and facilitated investigation of other aspects of river development, including river incision and formation of anthropogenic alluvium. The meta-analysis approach has also been expanded to include OSL ages alongside ${ }^{14} \mathrm{C}$ ages in the analysis of dated Holocene fluvial deposits, allowing a more comprehensive assessment of the variation in major flooding during the Holocene in regions in which OSL dating has been widely applied. 


\section{Acknowledgements}

This research was funded by the INQUA project “Hydrological EXtreme Events in Changing Climate- HEX Events (1220P)”. We wish to thank John Lewin and Eric Johnstone for their valued collaboration in developing the meta-analysis approach outlined in this paper.

\section{References}

Barber, K.E., Chambers, F.M., Maddy, D., Stoneman, R., Brew, J.S., 1994. A sensitive highresolution record of late Holocene climatic change from a raised bog in northern England. The Holocene 4, 198-205.

Benito, G., Thorndycraft, V.R., Rico, M., Sánchez-Moya, Y., Sopeña, A., 2008. Palaeoflood and floodplain records from Spain: Evidence for long-term climate variability and environmental changes. Geomorphology 101, 68-77.

Bond, G., Kromer, B., Beer, J., Muscheler, R., Evans, M.N., Showers, W., Hoffmann, S., Lotti-Bond, R., Hajdas, I., Bonani, G., 2001. Persistent solar influence on North Atlantic climate during the Holocene. Science 294, 2130-2136.

Bronk Ramsey, C., 2009. Bayesian analysis of radiocarbon dates. Radiocarbon 51, 337-360. Busschers, F.S., Kasse, C., van Balen, R.T., Vandenberghe, J., Cohen, K.M., Weerts, H.J.T., Wallinga, J., Johns, C., Cleveringa, P., Bunnik, F.P.M. 2007. Late Pleistocene evolution of the Rhine-Meuse system in the southern North Sea basin: imprints of climate change, sealevel oscillation and glacio-isostasy. Quaternary Science Reviews 26, 3216-3248.

Chiverrell, R.C., Thorndycraft, V.R., Hoffmann, T.O., 2011. Cumulative probability functions and their role in evaluating the chronology of geomorphological events during the Holocene. Journal of Quaternary Science 26, 76-85.

Ely, L.L., Enzel, Y., Baker, V.R., Cayan, D.R., 1993. A 5000-year record of extreme floods and climate change in the southwestern United States. Science 262, 410-412.

Foulds, S.A., Macklin, M.G., Brewer, P.A., 2013. The chronology and the hydrometeorology of catastrophic floods on Dartmoor, South West England. Hydrological Processess. DOI: 10.1002/hyp.9853.

Gregory, J.M., Jones, P.D., Wigley, T.M.L. 1991. Precipitation in Britain: an analysis of areaaverage data up to 1989. International Journal of Climatology 11, 331-345.

Gregory, K .J., Benito, G., Dikau, R., Golosov, V., Johnstone, E. C., Jones, J.A.A., Macklin, M. G., Parsons, A.J., Passmore, D. G., Poesen, J., Soja, R., Starkel, L., Thorndycraft, V. R. and Walling, D. E. (2006). Past hydrological events and global change. Hydrological Processes 20, 199-204. 
Harden, T., Macklin, M.G., Baker, V.R., 2010. Holocene flood histories in the southwestern United States. Earth Surface Processes and Landforms 35, 707-716.

Hoffmann, T., Lang, A., Dikau, R., 2008. Holocene river activity: analysing 14C-dated fluvial and colluvial sediments from Germany. Quaternary Science Reviews 27, 2031-2040. Johnstone, E., Macklin, M.G., Lewin, J., 2006. The development and application of a data base of radiocarbon-dated Holocene fluvial deposits in Great Britain. Catena 66, 14-23. Kale, V.S., 2007. Fluvio-sedimentary response of the monsoon-fed Indian rivers to Late Pleistocene-Holocene changes in monsoon strength: reconstruction based on existing 14C dates. Quaternary Science Reviews 26, 1610-1620.

Lewin, J., Macklin, M.G., 2003. Preservation potential for Late Quaternary river alluvium. Journal of Quaternary Science 18, 107-120.

Lewin, J., Macklin, M.G., Johnstone, E., 2005. Interpreting alluvial archives: sedimentological factors in the British Holocene fluvial record. Quaternary Science Reviews 24, 1873-1889.

Macklin, M.G., 1999. Holocene river environments in prehistoric Britain: human interaction and impact. Journal of Quaternary Science 14, 521-530.

Macklin, M.G., Benito, G., Gregory, K.J., Johnstone, E., Lewin, J., Michezyńska, D.J., Soja, R., Starkel, L., Thorndycraft, V.R., 2006. Past hydrological events reflected in the Holocene fluvial record of Europe. Catena 66, 145-154.

Macklin, M.G., Fuller, I.C., Jones, A.F., Bebbington, M., 2012a. New Zealand and UK Holocene flooding demonstrates interhemispheric climate asymmetry. Geology 40, 775-778. Macklin, M.G., Johnstone, E., Lewin, J., 2005. Pervasive and long-term forcing of Holocene river instability and flooding in Great Britain by centennial-scale climate change. The Holocene 15, 937-943.

Macklin, M.G., Jones, A.F., Lewin, J., 2010a. River response to rapid Holocene environmental change: evidence and explanation in British Catchments. Quaternary Science Reviews 29, 1555-1576.

Macklin, M.G., Tooth, S., Brewer, P.A., Noble, P.L., Duller, G.A.T. 2010b. Holocene flooding and river development in a Mediterranean steepland catchment: the Anapodaris Gorge, south-central Crete, Greece. Global and Planetary Change 70, 35-52.

Macklin, M.G., Jones, A.F., Lewin, J., 2011. Comment: Cumulative probability functions and their role in evaluating the chronology of geomorphological events during the Holocene.

Richard C. Chiverrell, Varyl R. Thorndycraft and Thomas O. Hoffmann in Journal of Quaternary Science 26: 76-85. Journal of Quaternary Science 26 238-240. 
Macklin, M.G., Lewin, J., 1993. Holocene river alluviation in Britain. Zeitschrift für Geomorphologie Supplement-Band 88, 109- 122.

Macklin, M.G., Lewin, J., 2003. River sediments, great floods and centennial-scale Holocene climate change. Journal of Quaternary Science 18, 101- 105.

Macklin, M.G., Lewin, J., Jones, A.F., 2013. River entrenchment and terrace formation in the UK Holocene. Quaternary Science Reviews, 76, 194-206.

Macklin, M.G., Lewin, J., Jones, A.F., 2014. Anthropogenic alluvium: an evidence-based meta-analysis for the UK Holocene. Anthropocene doi.org/10.1016/j.ancene.2014.03.003. Macklin, M.G., Lewin, J. and Woodward, J.C., 2012b. The fluvial record of climate change. Philosophical Transactions of the Royal Society A, 370, 2143-2172.

Macklin, M.G., Rumsby, B.T., 2007. Changing climate and extreme floods in the British uplands. Transactions of the Institute of British Geographers NS 32, 168-186.

Magny, M., 2004. Holocene climatic variability as reflected by mid-European lake-level fluctuations, and its probable impact on prehistoric human settlements. Quaternary International 113, 65-80.

Medialdea, A., Thomsen, K.J., Murray, A.S., Benito, G. 2014. Reliability of equivalent dose determination and age models in the OSL dating of historical and modern palaeoflood sediments. Quaternary Geochronology 22, 11-24.

Merrett, S. P., Macklin, M. G. 1999., Historic river response to extreme flooding in the Yorkshire Dales, northern England. In Brown, A G and Quine, T M (Eds), Fluvial Processes and Environmental Change, 345-360 Chichester, Wiley.

Michczyńska, D.J., Pazdur, A. 2004. Shape analysis of cumulative probability density function of radiocarbon dates set in the study of climate change in the Late Glacial and Holocene. Radiocarbon 46 (2), 733-744.

Piccarreta, M., Caldara, M., Capolongo, D., Boenzi, F., 2011. Holocene geomorphic activity related to climatic change and human impact in Basilicata, Southern Italy. Geomorphology 128, 137-147.

Reimer, P. J., Bard, E., Bayliss, A., Beck, J. W., Blackwell, P. G., Bronk Ramsey, C., Grootes, P. M., Guilderson, T. P., Haflidason, H., Hajdas, I., Hatté, C., Heaton, T. J., Hoffmann, D. L., Hogg, A. G., Hughen, K. A., Kaiser, K. F., Kromer, B., Manning, S. W., Niu, M., Reimer, R. W., Richards, D. A., Scott, E. M., Southon, J. R., Staff, R. A., Turney, C. S. M., van der Plicht, J., 2013. IntCal13 and Marine13 Radiocarbon Age Calibration Curves 0-50,000 Years cal BP. Radiocarbon, 55, 1869-1887. 
Richardson, J.M., Fuller, I.C., Macklin, M.G., Jones, A.F., Holt, K.A., Litchfield, N.J., Bebbington, M., 2013. Holocene river behaviour in New Zealand: response to regional centennial-scale climate forcing. Quaternary Science Reviews 69, 8-27.

Sim, A.K., Thomsen, K.J., Murray, A.S., Jacobsen, G., Drysdale, R., Erskine, W. 2014. Dating recent floodplain sediments in the Hawkesbury-Nepean River system, eastern Australia using single-grain quartz OSL. Boreas 43, 1-21.

Starkel, L., Soja, R., Michczyńska, D.J., 2006. Past hydrological events reflected in Holocene history of Polish rivers. Catena 66, 24-33.

Suess, H.E., 1955. Radiocarbon concentration in modern wood. Science 122, 415-417. Thorndycraft, V.R., Benito, G., 2006a. Late Holocene fluvial chronology of Spain: the role of climatic variability and human impact. Catena 66, 34-41.

Thorndycraft, V.R., Benito G., 2006b. The Holocene fluvial chronology of Spain: Evidence from a newly compiled radiocarbon database. Quaternary Science Reviews 25, 223-234. Thorndycraft, V.R., Benito, G., Sánchez-Moya, Y., Sopeña, A., 2012. Bayesian age modelling applied to palaeoflood geochronologies and the investigation of Holocene flood magnitude and frequency. The Holocene 22, 13-22.

Turner, J.N, Macklin, M.G., Jones, A.F. and Lewis, H. 2010. New perspectives on Holocene flooding in Ireland using meta-analysis of fluvial radiocarbon dates. Catena 82, 183-190. Williams, A.N. 2012. The use of summed radiocarbon probability distributions in archaeology: a review of methods. Journal of Archaeological Science 39, 578-589. Zielhofer, C., Faust, D., 2008. Mid- and late Holocene fluvial chronology of Tunisia. Quaternary Science Reviews 27, 580-588. 